\title{
PENGARUH TRUST TERHADAP BERBAGI PENGETAHUAN MELALUI MEDIASI KOMITMEN ORGANISASI PADA DOSEN PERGURUAN TINGGI
}

\author{
Ery Faisal Badar ${ }^{1}$ dan Ali Nina Liche Seniati ${ }^{2}$ \\ Program Magister Sains \\ Fakultas Psikologi Universitas Indonesia \\ erybadar@gmail.com \\ lichechairy@yahoo.co.id
}

\begin{abstract}
Sharing knowledge is a basic thing in a good organization of business or educational organizations such as in Higher Education. Colleges are educational organizations where knowledge is often created and used continuously and continuously. Sharing knowledge not only lecturers to students but also to fellow colleagues. This study aims to determine the perception of lecturers in sharing knowledge. Lecturer as one of the resources of Higher Education, has two types of knowledge that is explicit knowledge (data and documents) and also tacit knowledge (knowledge that is subjective and experiencebased). These two types of knowledge are important assets in the organization that must be communicated between individuals and organizations. This is so that the process of sharing knowledge (knowledge sharing) goes well to support various decisions. Creation of knowledge within an organization is achieved through an understanding of the process of transforming existing tacit knowledge into easily communicated and easily documented knowledge, and through the design of social processes by transferring the tacit knowledge into explicit knowledge to create a new knowledge. The sharing of knowledge within a Educational organizations such as Higher Education are influenced by such things as trust and organizational commitment. Trust and organizational commitment affect the extent to which lecturers will share the knowledge of their colleagues. The higher the trust between lecturers and coworkers as well as organizational commitment within an educational organization, then there will be a tremendous trend for them to share their knowledge.
\end{abstract}

Keywords: Sharing Knowledge, Organizational Commitment, and Trust

Abstrak. Berbagi pengetahuan merupakan hal dasar dalam sebuah organisasi baik orgnasasi bisnis maupun pendidikan seperti pada Perguruan Tinggi. Perguruan tinggi adalah organisasi pendidikan dimana knowledge (pengetahuan) banyak diciptakan dan digunakan secara terus menerus dan berkesinambungan. Berbagi pengetahuan tidak hanya dosen kepada mahasiswa tetapi juga kepada sesama kolega. Penelitian ini bertujuan untuk mengetahui persepsi dosen dalam berbagi pengetahuan. Dosen sebagai salah satu sumber daya Perguruan Tinggi, memilik dua jenis pengetahuan yaitu explicit knowledge (data maupun dokumen) dan juga tacit knowledge (pengetahuan yang bersifat subjektif serta berbasis pengalaman. Kegiatan berbagi pengetahuan di dalam sebuah organisasi pendidikan seperti Perguruan Tinggi dipengaruhi oleh beberapa hal seperti trust dan komitmen organisasi. Trust dan komitmen organisasi mempengaruhi sejauh mana dosen akan berbagi pengetahuan sesama koleganya. Semakin tinggi trust antara dosen dan rekan kerja serta komitmen organisasi dalam sebuah organisasi pendidikan, maka akan terdapat kecenderungan yang sangat besar bagi mereka untuk melakukan berbagi pengetahuan.

Kata kunci : Berbagi Pengetahuan, Komitmen Organisasi, dan Trust

\section{PENDAHULUAN}

Pada era yang berbasis ilmu

pengetahuan seperti saat ini, pengetahuan akan menjadi dasar daya saing organisasi. Pengetahuan memberi keunggulan kompetitif yang berkelanjutan 
bagi organisasi dalam ajang persaingan yang kompetitif dan dinamis (Davenport \& Prusak, 1998; Foss \& Pedersen, 2002; Nonaka, 2002). Pengetahuan dapat dianggap sebagai kunci dari keunggulan organisasi karena kinerja suatu organisasi akan dipengaruhi oleh pemanfaatan sumber daya intelektual dari para karyawan di dalamnya (Nonaka, 2002). Dilihat dari pentingnya peran pengetahuan bagi organisasi, jelas bahwa pengetahuan sebagai sumber daya organisasi harus dimanfaatkan. Pengetahuan akan menjadi sumber daya yang merupakan keunggulan kompetitif organisasi hanya jika digunakan secara efektif dan digunakan sebagai dasar untuk menghasilkan pengetahuan baru (Alavi \& Leidner, 2001; Cross \& Baird, 2000; Hussi, 2004). Dengan demikian, organisasi harus menyadari bahwa pengelolaan pengetahuan adalah kunci dari keberhasilan kinerja organisasi (Leonard \& Swap, 2004).

Individu, organisasi, dan ekonomi telah memberikan nilai yang tinggi dan perhatian yang khusus terhadap ilmu pengetahuan dan bagaimana ilmu pengetahuan tersebut di kelola menjadi sebuah keunggulan bagi mereka sehingga memunculkan pertumbuhan angka dari literatur-literatur dalam manajemen pengetahuan dan prosesnya yang salah satunya adalah knowledge sharing (berbagi pengetahuan). Teori-teori yang berdasarkan pengetahuan (knowledgebased theories) menempatkan poin penting dimana tujuan fundamental dari setiap organisasi adalah mengintegrasikan ilmu pengetahuan (Nonaka et al., 2000; Grant, 1996).

Manajemen

pengetahuan

(knowledge management) tidak hanya penting bagi dunia bisnis, namun juga sangat penting dalam sektor organisasi yang bergerak dalam bidang pendidikan yang termasuk di dalamnya adalah pendidikan tingkat tinggi (Prahalad dan Hamel, 1990).

Penelitian-penelitian berbagi pengetahuan terdahulu banyak di dominasi oleh penelitian pada organisasi bisnis. Hal ini bisa dimaklumi karena tujuan utama dari berbagi pengetahuan di dalam organisasi adalah keuntungan bagi perusahaan. Namun, isu-isu berbagi pengetahuan sama pentingnya bagi institusi knowledge-based, seperti universitas, dimana pengetahuan diciptakan, didistribusikan, dan diaplikasikan di dalam institusi tersebut. Manajemen pengetahuan didalam institusi belajar tingkat tinggi seperti Universitas lebih terfokus kepada aktifitas menerima, membuat, menyimpan, berbagi, dan mengelola ilmu pengetahuan dengan tujuan untuk mencapai target dari institusi tersebut (Ridzuan et al. 2008). Ketika fakultas menjadi komponen utama di dalam kolaborasi dan berbagi pengetahuan, persepsi dan perilaku individu terhadap berbagi pengetahuan menjadi poin penting dalam proses manajamen pengetahuan dimana fakultas ataupun kampus menjadi pusat atau gudangnya ilmu pengetahuan (Kim dan Ju, 2008).Walaupun belum terdapat cara langsung untuk mengukur hasil dari berbagi pengetahuan di dalam intitutsi pendidikan, efek dari berbagi pengetahuan di dalam institusi pendidikan bisa lebih besar jika dibandingkan dengan organisasi atau institusi yang berorientasi bisnis (Cheng, Ho, dan Lau, 2009).

Perguruan tinggi adalah organisasi dimana knowledge (pengetahuan) banyak diciptakan dan digunakan secara terus menerus dan berkesinambungan. Penciptaan knowledge dalam sebuah organisasi tercapai melalui pemahaman terhadap hubungan proses mengubah tacit knowledge yang ada menjadi knowledge yang mudah dikomunikasikan dan mudah didokumentasikan, serta 
melalui desain proses sosial dengan mengalihkan tacit knowledge ke dalam explicit knowledge untuk menciptakan sebuah knowledge baru. Salah satu knowledge yang perlu dimiliki oleh perguruan tinggi adalah bagaimana mengelola dengan baik sistem informasi akademik yang ada, sehingga dapat menunjang kegiatan lain, seperti penugasan, materi, serta informasi akademik lainnya.

Penelitian terdahulu mengelompokkan faktor-faktor penyebab berbagi pengetahuan di dalam organisasi menjadi dua faktor yaitu faktor organisasi dan faktor individu serta faktor teknologi. Bollinger dan Smith (2001) berpendapat bahwa perilaku para manusia merupakan kunci kesuksesan atau kegagalan sebuah strategi manajemen pengetahuan. Berbagi pengetahuan (knowledge sharing) pada dasarnya sebuah prinsip pengorganisasian, yang meletakkannya sebagai hal dasar untuk mengembangkan potensi pengetahuan yang dimiliki dalam sebuah organisasi. Untuk membuat sebagian besar dari sumber daya organisasi dan meningkatkan berbagi pengetahuan, adalah suatu hal yang penting bahwa untuk mengelola teknologi dan orang-orang dalam rangka menyediakan lingkungan berbagi pengetahuan yang bermanfaat. Hoff dan Weenen (2004) mendefinisikan berbagi pengetahuan sebagai perilaku dimana karyawan saling bertukar pengetahuan mereka (tacit knowledge dan eksplicit knowledge). Setiap perilaku berbagi pengetahuanterdiri dari membawa atau menyumbangkan pengetahuan (berkomunikasi kepada orang lain mengenai modal intelektual pribadi) dan mendapatkan atau mengumpulkan pengetahuan (konsultasi dengan rekan kerja agar bersedia untuk berbagi modal intelektual mereka). Berbagi pengetahuanantar karyawan memungkinkan organisasi untuk memanfaatkan pengetahuan yang telah ada (Cabrera \& Cabrera, 2002; Damodaran \& Olphert, 2000). Dari beberapa penelitian telah ditemukan bahwa berbagi pengetahuanberhubungan dengan penurunan biaya produksi, pengembangan produk baru, peningkatan kinerja karyawam, inovasi, serta peningkatan penjualan dan pendapat dari produk baru (Arthur \& Huntley, 2005; Cummings, 2004; Collins \& Smith, 2006; Lin, 2007; Mesmer-Magnus \& DeChurch, 2009). Karena manfaatnya ini, berbagi pengetahuandiduga dapat mempengaruhi kinerja in-role individu (Kim \& Lee, 2006).

Faktor-faktor yang mempengaruhi berbagi pengetahuan dibagi menjadi dua kelompok. Pertama, faktor yang berasal dari organisasi, seperti kultur organisasi (Cavaliere \& Lombardi, 2015), leadership, rewards, dan insentif (Tsai, 2002; Wasko \& Faraj, 2005), serta trust (Joo \& Jo, 2011; Robertson \& Hammersley, 2000). Faktor kedua yang berasal dari faktor yang berasal dari individu, meliputi personality, knowledge self efficacy (Wang \& Lai, 2006; Wasko \& Faraj, 2005), kepuasan kerja(de Vries, van den Hoof, de Ridder, 2010), organization citizenship behavior atau OCB (Jo \&Joo, 2011), dan komitmen organisasi (lyer \& Ravindran, 2013; Davenport \& Prusak, 1998). Banyak penelitian selama ini lebih difokuskan pada penelitian organisasi, sementara faktor individu masih kurang banyak diteliti (Wang \& Noe, 2010). Padahal individu merupakan faktor terpenting pada berbagi pengetahuan di dalam manajemen pengetahuan (Alavi \& Leidner, 2001; Davenport \& Prusak, 1998; Kankahalli, Tan, \& Wei, 2005) dan menjadi alasan kegagalan berbagi pengetahuan(Carter \& Scarbrough, 2001; Voelpel, Dous, \& Davenport, 2005).

Menanggapi pentingnya faktor individu dan faktor organisasi dalam studi berbagi pengetahuan, maka penelitian ini akan berfokus pada faktor individu dan 
faktor organisasi sekaligus dalam mengkaji berbagi pengetahuan. Faktor individu dan organisasi yang akan dikaji lebih jauh dalam penelitian ini meliputi kepercayaan (trust) dan komitmen organisasi.

Salah satu faktor organisasi yang mempengaruhi berbagi pengetahuan yang akan difokuskan dalam penelitian ini adalah komitmen organisasi (Gray and Densten, 2005). Komitmen organisasi karyawan dalam bekerja dapat menjadi keunggulan kompetitif yang signifikan bagi organisasi (Wang \& Noe, 2010). Komitmen organisasi telah didefinisikan dan dikonsepkan dengan berbagai macam cara beberapa dekade terakhir ini. Bahkan saat ini ada sejumlah variasi yang muncul yang berhubungan dengan bagaimana komitmen didefinisikan, dimensi konstruk, faktor yang mempengaruhi komitmen, dan dampak komitmen terhadap organisasi (Mayer, Becker, \& Vandenbergher, 2004). Komitmen organisasi didefinisikan sebagai derajat keterikatan seorang karyawan dengan organisasinya dan keinginan karyawan untuk mengerahkan segala usaha atas nama organisasinya (Wang \& Noe, 2010). Ketika individu memiliki ikatan psikologis dengan perusahaan, maka individu akan menginternalisasi dan mengadopsi karakteristik ataupun pandangan dari organisasi (O'Reilly \& Chatman, 1986). Ketika individu berkomitmen terhadap suatu perusahaan, maka individu tersebut menerima dan percaya akan tujuan dan nilai perusahaan sehingga individu mau memberikan usaha lebih terhadap organisasi dan tetap menjaga keanggotaannya di dalam organisasi (Burud, \& Tumolo, 2004).

Komitmen organisasi telah ditemukan terkait dengan organizational variables, seperti turnover, kepuasan kerja, sense of obligation, dan altruism (Meyer et al., 1993; O'Reilly and Chatman, 1986). Meyer dan Allen (1997) berargumentasi bahwa komitmen afektif secara positif terkait dengan keinginan individu dengan komitmennya untuk bekerja lebih keras terhadap pekerjaan mereka, jenis komitmen ini diharapkan terkait dengan keinginan untuk memberikan dan menerima ilmu pengetahuan. Beberapa penelitian menemukan hubungan yang positif antara komitmen organisasi terhadap berbagi pengetahuan (Casimir, Lee, \& Loon, 2012; Hislop, 2003; Flynn, 2005; Chiang, Han, \& Chuang, 2011).

Beberapa faktor individu yang berpengaruh dalam berbagi pengetahuan adalah trust (kepercayaan). Salah satu faktor individu yang penting untuk diteliti adalah trust karena merupakan syarat utama dalam knowledge sharing (Cheng \&Li, 2006; Qian dkk., 2008). Dalam penelitian yang dilakukan oleh Hoff dan Weenen (2004) ditemukan bahwa semakin tinggi trust antara manajemen dan rekan kerja dalam sebuah organisasi, maka akan terdapat kecenderungan yang sangat besar bagi mereka untuk melakukan berbagi pengetahuan. Berbagi pengetahuanakan dapat berjalan dengan maksimal jika kepercayaan diantara rekan kerja terbangun dengan baik karena pemilik pengetahuan lebih memilih untuk membagi pengetahuan yang dimilikinya dengan orang yang dapat dipercayai. Pada kenyataannya, berbagi pengetahuan ini bukan hanya sekedar transfer informasi yang sederhana, tetapi juga mencakup proses berbagi ide, sikap,nilai, dan asumsi. Johannessen, Olaisen, dan Olsen (2001) mengemukakan bahwa trust adalah kunci dalam berbagi pengetahuan dalam dan antar organisasi. Oleh karena itu berbagi pengetahuan mustahil terjadi jika tidak ada trust yang terbangun di antara individu dalam organisasi (Szulanski \& Jensen, 2004).

Menurut McAllister (1995) trust terbagi ke dalam dua bentuk. Bentuk pertama adalah affect based trust, yaitu 
kecenderungan untuk percaya akan ketulusan atau niat baik seseorang dan yakin bahwa hubungan tersebut saling berbalas. Bentuk kedua adalah cognitive based trust, yaitu kecenderungan untuk percaya akan kemampuan dan kompetensi rekan kerja. Pada bentuk kedua ini rasa percaya dan hormat kepada orang lain karena bukti kompetensi, tanggung jawab,dan kehandalan yang dimilikinya menjadi kriteria yang digunakan untuk menilai kepercayaan. Penelitian - penelitian terdahulu mengenai hubungan trust dan berbagi pengetahuan, cenderung fokus hanya pada cognitive based trust (Forsyth,2006; Liang, Liu, \& Wu, 2008; McEvily, Perrone, \& Zaheer, 2003) dan melupakan hubungan affect based trust dengan berbagi pengetahuan.

Penelitian ini dilakukan pada Universitas negeri maupun swasta di Indonesia dengan fokus subjek penelitiannya adalah dosen. Hal ini didasari berdasarkan data empiris dari Ramachandran et al. (2009) yang menyatakan bahwa terdapat perbedaan yang signifikan dalam hal praktek penyebaran ilmu pengetahuan pada Universitas negeri dengan Universitas swasta.

Universitas merupakan sebuah lingkungan yang mendorong dan memiliki peran yang penting dalam menciptakan ilmu pengetahuan melalui penelitian, yang kemudian dipublikasikan. Universitas juga memegang peranan penting lewat kerjasamanya dengan bidang bisnis dan organisasi lainnya dalam mendukung inovasi, serta mendukung pembelajaran melalui pengaharan dan program pelatihan penelitian. Oleh karena itu bisa dikatakan bahwa seharusnya Universitas menjadi tempat dimana pengembangan strategi manajemen ilmu pengetahuan perlu sangat diterapkan (Fullwood, Rowley, dan Delbridge, 2012). Universitas juga merupakan tempat dimana akademisi menyadari bahwa pentingnya berbagi pengetahuan dan saling bertukar ilmu pengetahuan dengan koleganya dalam kegiatan mereka setiap hari. Namun, pada kenyataannya, berbagi ilmu hampir tidak terjadi di universitas-universitas pada akhir-akhir ini (Ridzuan et al. 2008). Rendahnya keinginan untuk berbagi ilmu pengetahuan menjadi hal yang umum terjadi pada kalangan akademisi atau dosen yang pada penelitian Kim dan Ju (2008) memberikan fakta bahwa para akademisi lebih cenderung menempatkan prioritas pribadi mereka dalam bentuk penghargaan pribadi dibandingkan dengan berbagi visi mereka dengan sesamanya yang bermuara kepada tercapainya misi-misi yang telah dicanangkan oleh universitas. Individuindividu dari institusi akademis ini menempatkan faktor pencapaian pribadi dan mengajar dibandingkan dengan berbagi visi terhadap tujuan dan sasaran dari organisasi tersebut. Konsekuensinya adalah tergolong rendahnya keinginan individu untuk berbagi pengetahuan dengan tujuan mencapai tujuan atau sasaran pada para akademisi jika dibandingkan dengan perusahan yang profit-oriented. Berdasarkan keunikan karakter dari exclusiveness dan individualis ini, berbagi pengetahuan dan knowledge management pada organisasi akademisi cenderung tidak sistematis dan bisa menjadi tidak efisien. Hal ini bisa mengarah kepada rendahnya penggunaan sumber-sumber daya yang ada dan rendahnya kesempatan untuk belajar (Kim dan Ju, 2008).

Kecenderungan para akademisi atau dosen yang secara tidak langsung membatasi perilaku berbagi pengetahuan mereka terjadi ketika individu-individu ini mempunyai pengetahuan yang spesial, unik, ataupun penting yang para individu lainnya tidak miliki. Selain itu, kecenderungan individu curiga terhadap 
ilmu pengetahuan orang lain merupakan salah satu bentuk dari kecenderungan alami yang dimiliki manusia (Davenport dan Prusak, 1998). Hal ini juga didorong oleh insting pembelaan diri, mereka tidak ingin berbagi ilmu pengetahuan karena mereka menganggap ilmu yang mereka adalah aset berharga yang tidak bisa diberikan secara cuma-cuma dan pada kasus institusi perguruan tinggi, banyak akademisi gagal dalam memahami fakta bahwasanya apabila mereka saling bekerja sama sesama para akademisi bisa memberikan efektifitas yang lebih baik untuk perguruan tinggi tersebut (Kogut dan Zander, 1996). Kim dan Ju (2008) memaparkan bahwa akademisi sebagai anggota dari sebuah fakultas di dalam institusi akademis menjadi ujung tombak yang penting dalam merepresentasikan institusi mereka karena kemampuan mereka dalam memproduksi dan mendaur ulang ilmu pengetahuan. Para akademisi dan dosen menjadi aset yang penting yang dimiliki oleh Universitas. Oleh karena itu akademisi juga ikut memiliki tanggung jawab dalam berbagi sumber-sumber yang berkualitas dan keahlian mereka bagi masyarakat sehingga hal diatas mengarahkan kepada pertanyaan tentang bagaimana fenomena berbagi ilmu pengetahuan dikalangan para akademisi.

Menurut Becerra-Fernandez et. al. (2004), pengetahuan dapat dibedakan dari data dan informasi dengan 2 (dua) cara, yaitu :

1. Cara pertama yaitu cara pandang sederhana dengan menempatkan pengetahuan pada level tertinggi dalam suatu hierarki sementara informasi pada level menengah dan data pada level terendah. Berdasarkan cara pandangini, pengetahuan merujuk kepada informasi yang mendukung pengambilan tindakan dan keputusan, atau informasi yang dilengkapi dengan petunjuk. Sedangkan data merujuk kepada fakta murni yang tidak mengandung suatu konteks dan informasi dilihat sebagai suatu data yang sudah memiliki konteks.

2. Cara kedua yaitu dengan mendefinisikan pengetahuan berada di dalam suatu wilayah sebagaimana menunjukkan kebenaran mengenai hubungan antara konsep-konsep yang berkaitan dengan wilayah khusus tersebut.

\section{Tipe Pengetahuan}

Klasifikasi pengetahuan yang dipaparkan oleh Nonaka dan Takeuchi (1995) membagi tipe knowledge menjadi dua jenis yaitu pengetahuan tasit (tacitknowledge) dan pengetahuan eksplisit (explicit knowledge). Hal ini untuk memahami bagaimana pengetahuan dibentuk dan dapat diterapkan.

1. Pengetahuan eksplisit dapat diproses dengan komputer, ditransmisikan secara elektronik, atau disimpan dalam basis data. Pengetahuan eksplisit merupakan pengetahuan yang bersifat objektif dan rasional. Tipe pengetahuan ini dapat dinyatakan dalam kata-kata, kalimat, angka atau rumus. Hal ini termasuk pendekatan teori, pemecahan masalah, buku petunjuk, dan basis data.

2. Pengetahuan tasit bersifat personal dan khusus, hanya dapat diekstrak oleh manusia. Pengetahuan tasit merupakan subjektif dan pengalaman berdasarkan pengetahuan yang tidak dapat diungkapkan dengan kata-kata, kalimat, angka, atau formula. Hal ini meliputi ketrampilan kognitif seperti keyakinan, gambar, intuisi, dan model mental serta ketrampilan teknis seperti keahlian dan know-how.

Knowledge dalam KM bisa berasal dari manusia, artefak maupun entitas organisasi. Manusia berperan sebagai sumber knowledge baik secara individu 
maupun kelompok. Sumber knowledge lainnya yaitu artefak berupa terapan kebiasaan/aturan, teknologi dan repositori seperti dokumen-dokumen. Sedangkan knowledge yang berasal dari entitas organisasi bisa berasal dari unit organisasi, organisasi lain dan jaringan antar organisasi.

\section{Knowledge Management}

Ada berbagai definisi mengenai knowledge management, antara lain:

1. Knowledge management adalah hasil dari sumber daya yang ada saat ini yang sudah dimiliki organisasi - manajemen sistem informasi yang baik, manajemen perubahan organisasi, dan praktekpraktek manajemen SDM (Davenport dan Prusak, 1998).

\section{Knowledge management adalah} manajemen yang eksplisit dan sistematik dari pengetahuan vital dan proses menciptakan, mengumpulkan, mengorganisasi, menyebarkan, menggunakan dan mengeksploitasi pengetahuan tersebut dalam mencapai tujuan organisasi (Skyrme, 1999).

\section{Knowledge management merupakan} proses-proses yang perlu dilakukan untuk menciptakan, menangkap, mengkodekan, dan mentransfer knowledge edalam organisasi untuk mencapai manfaat secara kompetitif (Becerra-Fernandez et. al. (2004).

Dari beberapa definisi diatas, dapat disimpulkan bahwa KM merupakan proses penciptaan, penyebaran, dan pemindahan pengetahuan karyawan untuk meningkatkan kinerja organisasi. KM melibatkan berbagai kegiatan meliputi people, process, dan technology yang mendukung perlindungan, pengembangan, dan pemanfaatan aset pengetahuan. Dengan mengelola modal intelektual yang ada baik dalam bentuk eksplisitmaupun tasit, KM meningkatkan kemampuan organisasi untuk belajar dari lingkungannya dan untuk memasukkan pengetahuan ke dalam proses bisnis. Hal tersebut menciptakan nilai baru bagi organisasi dengan meningkatkan efisiensi, efektivitas, dan proses inovasi dalam mempertahankan daya saing.

\section{Proses Knowledge Management}

Berdasarkan definisi yang dikemukakan oleh Becerra-Fernandez et. al. (2004), KM terdiri dari empat proses utama yaitu :

\section{Knowledge Discovery}

"Knowledge discovery may be defined as the development of new tacit orexplicit knowledge from data and information or from synthesis of priorknowledge". Menurut mereka definisi dari knowledge discovery adalah membangun tacitatau eksplisit knowled tacit atau explicit knowledge baru dari data dan informasi atau dari sintesis pengetahuan terdahulu.

\section{Knowledge Capture}

"Knowledge capture may be defined as the process ofretrieving either tacit orexplicit knowledge that resides within people, artifacts, or organizationalentities". Menurut mereka knowledge capture adalah proses perbaikan salah satu dari tacit atau explicit knowledge yang melalui orang, artefak atau entitas organisasi.

\section{Knowledge Sharing (Berbagi Pengetahuan)}

"Knowledge sharing is the process through which explicit or tacit knowldegeis communicated to other individuals". Menurut mereka berbagi pengetahuan adalah proses dimana explicit atau tacit knowledge dapat dikomunikasikan dengan individu lainnya.

\section{Knowledge Application \\ "Knowledge application is the process through which some individulas utilizeknowledge possessed by other}


individuals without actually acquiring orlearning that knowledge". Menurut mereka knowledge application adalah proses penggunaan pengetahuan yang dipunyai oleh beberapa individu dengan individu lain tanpa mendapatkan secara nyata atau mempelajari pengetahuan itu.

Dalam penelitian ini yang akan menjadi fokus penelitian adalah tentang berbagi pengetahuan (knowledge sharing).

Bollinger dan Smith (2001) berpendapat bahwa perilaku para manusia merupakan kunci kesuksesan atau kegagalan sebuah strategi manajemen pengetahuan. Berbagi pengetahuan (knowledge sharing) pada dasarnya sebuah prinsip pengorganisasian, yang meletakkannya sebagai hal dasar untuk mengembangkan potensi pengetahuan yang dimiliki dalam sebuah organisasi.

Berbagi pengetahuanmerupakan komponen yang penting dari efektifivitas penerapan knowledge management di perusahaan (Gupta \& Govindarajan, 2000). Terdapat beberapa pengertian dari berbagai peneliti. Boyd (2007) mendefinisikan bahwa berbagi pengetahuanmelibatkan interaksi sosial dan merupakan proses dua arah yang terjadi secara sukarela. Hoff dan Weenen (2004) mendefinisikan berbagi pengetahuansebagai perilaku dimana karyawan saling bertukar pengetahuan mereka (tacit knowledge dan eksplicit knowledge). Setiap perilaku berbagi pengetahuanterdiri dari membawa atau menyumbangkan pengetahuan (berkomunikasi kepada orang lain mengenai modal intelektual pribadi) dan mendapatkan atau mengumpulkan pengetahuan (konsultasi dengan rekan kerja agar bersedia untuk berbagi modal intelektual mereka). Tuomi (1999) mendefinisikan berbagi pengetahuansebagai prasyarat untuk knowledge transfer dan knowledge creation. Davenport dan Prusak (1998) mendefinisikan berbagi pengetahuansebagai pertukaran ide, pengalaman, dan pengetahuan di antara individu dan kelompok. Wang dan Noe (2010) mendefinisikan berbagi pengetahuansebagai penyediaan informasi dan pengetahuan (know-how) untuk membantu dan berkolaborasi dengan orang lain dalam penyelesaian suatu masalah pengembangan ide baru atau penerapan kebijakan. Proses berbagi pengetahuanterjadi ketika individu saling bertukar pengetahuan dan bersama-sama menciptakan pengetahuan baru.

Berdasarkan definisi diatas, maka peneliti menyimpulkan bahwa definisi berbagi pengetahuan oleh Hoff dan Weenen (2004) sebagai definisi utama dan alat ukur yang akan digunakan untuk penelitian ini.

Terdapat beberapa faktor yang dapat mendorong atau melatar belakangi perilaku berbagi pengetahuan. Menurut Cumming (2004) terdapat beberapa elemen yang mendukung terbentuknya proses berbagi pengetahuan, pertama struktur organisasi dengan lapisan yang lebih sedikit dan lebih menekankan pada teamwork. Keduareward system dan training, ketiga budaya organisasi yang mendukung trial and error, keterbukaan dan kreativitas karyawan. Sedangkan Schauer dkk (2015) berpendapat bahwa terdapat empat faktor yang mempengaruhi persepsi individu terhadap berbagi pengetahuan, yaitu sharer, institusi, relations, dan knowledge.

Gagne (2009) melakukan penelitian empiris dan mengidentifikasi faktor yang mempengaruhi berbagi pengetahuan, yang mencakup faktor individu sebagai faktor pertama, misalnya hilangnya kepercayaan, ketakutan akan hilangnya kekuasaan, dan knowledge self efficacy. Kedua adalah faktor organisasi, misalnya kepemimpinan, tidak ada sistem imbalan yang tepat, budaya organisasi, struktur 
organisasi, dan yang ketiga adalah faktor teknologi, yaitu sistem informasi yang kurang (Ipe, 2003).

Riege (2005) berpendapat bahwa dalam beberapa diskusi terhadap knowledge sharing barriers, banyak penelitian fokus terhadap budaya organisasi dan budaya nasional. Studi lainnya mendiskusikan gagasan tentang organisasional atau collective knowing yang erat kaitannya dengan istilah budaya organisasi. Studi lainnya berkonsentrasi terhadap sifat perusahaan sebagai komunitas sosial atau pentingnya social capital dan interaksi sosial dalam memfasilitasi pembentukan dan berbagi pengetahuan. Peneliti lainnya menyimpulkan bahwa berbagi ilmu turut berkontribusi terhadap performa dari organisasi atau perusahaan walaupun efektivitas dari sharing activity goals dan strateginya sulit untuk diukur dikarenakan perbedaan yang terdapat pada setiap perusahaan. Perbedaan tersebut bisa saja berdasarkan individu (kurangnya interpersonal skills), struktur, proses, dan sistem di dalam organisasi ataupun teknologi. Terdapat pula peneliti-peneliti yang berfokus kepada isu trust diantara para karyawan (Kim \& Ju, 2008;Wang and Noe, 2010; Casimir et al., 2012; Wickramasinghe and Widyaratne, 2012), reward (Yao, Kam, \& Chan, 2007; Kim and Lee, 2006), OCB dan komitmen (Hislop, 2003; Liang, Liu, \& Wu, 2008; Jo \& Kyoo, 2011; lyer \& Ravindran, 2013; Davenport \& Prusak, 1998).

Terdapat beberapa alat ukur untuk mengukur variabel berbagi pengetahuan. Pengukuran berbagi pengetahuan yang pertama menggunakan alat ukur berbagi pengetahuandari Bock et al (2005), dengan dua dimensi yang terdiri dari attitude toward berbagi pengetahuandengan cronbach alpha 0,91dan intention to share tacit and explicit knowledge dengan cronbach alphatacit knowledge 0,92 dan cronbach alpha explicit knowledge 0,93. Untuk alat ukur selanjutnya adalah alat ukur yang dikembangkan oleh Hoff dan Wenan (2004). Alat ukur ini memiliki 9 aitemdengan bentuk skala likert dengan 6 pilihan jawaban dan memiliki cronbach alpha 0,87 .Sejauh penelusuran peneliti, kedua alat ukur di atas sering digunakan sebagai alat ukur untuk mengukur berbagi pengetahuan.

\section{Trustdan Berbagi Pengetahuan}

Trustdapat didefinisikan sebagai keinginan seseorang untuk mempercayai individu lain didasarkan atas tindakan yang menguntungkan dari individu tersebut (Chowdury, 2005). Di sisi lain menurut Mayer (1995) trustdidefinisikan sebagai keinginan seseorang (trustor) untuk melakukan suatu tindakan yang didasarkan atas ekspektasi pada individu lain (trustee). Moordian dkk (2006) menyatakan bahwa trustadalah sebuah konstruk sikap, dimana ekspektasi individu terhadap orang lain terkait dengan pengalaman individu tersebut sebelumnya terhadap orang tertentu seperti manajer atau rekan kerja. Trustmengacu pada suatu keyakinan tertentu terutama yang berkaitan integritas dan kemampuan orang lain (Chiu, Hsu, \& Wang, 2006).

Teori pertukaran sosial (Blau, 1964) menyatakan bahwa seorang individu senang membangun hubungan pertukaran dengan orang lain, memberikan keuntungan kepada orang lain, dan kemudian mengharapkan mendapatkan imbalan di masa depan. Blau (1964) menyatakan bahwa kepercayaan adalah faktor penting untuk proses pertukaran sosial. Semakin tinggi derajat trustyang dirasakan oleh pemberi dan penerima, maka semakin kuat hubungan pertukaran sosial yang ada antara mereka (Blau, 1964; Wasko \& Faraj, 2005). Banyak peneliti menyetujui bahwa trustmerupakan 
konsep yang sifatnya multi dimensional. Pada penelitian ini, peneliti menggunakan pendekatan trustyang dikemukakan oleh McAllister (1995), pendekatan ini banyak digunakan untuk meneliti hubungan trustdan berbagi pengetahuan(Chowdhury, 2005, Qian dkk, 2008, Holste \& Fields, 2010). Pendekatan ini lebih terfokus pada kondisi dalam organisasi yang meliputi interaksi di antara karyawan (Qian dkk, 2008). McAllister mengembangkan dan menguji secara empiris dua bentuk yang berbeda dari interpersonal trustyaitu : (a) affect based trustyaitu kecenderungan untuk percaya akan ketulusan atau niat baik seseorang. Affect based trustmengacu kepercayaan dari hati (trust from the heart), ikatan berdasarkan empati, perasaan,dan kedekatan emosional. Dengan trustini, individu mengekspresikan kepedulian dan perhatian untuk kebaikan dan kesejahteraan rekan kerja (Chua, Ingram, \& Morris, 2008). Affect based trustbiasanya melibatkan ikatan emosional, lebihbertahan lama, dan lebih dapat digeneralisasi pada berbagai situasi dibandingkan dengan cognitive based trust(Chua dkk, 2008; Lewicky \& Bunker, 1996), sedangkancognitive based trustyaitu kecenderungan untuk percaya akan kemampuan dan kompetensi rekan kerja. Kita cenderung percaya dan menghormati orang lain karena adanya alasan dan bukti dari kompetensi, tanggung jawab, kehandalan sebagai kriteria yang digunakan untuk menilai kepercayaan. Kepercayaan yang dibangun berdasarkan informasi, bukti tentang perilaku individu lain dalam keadaan tertentu (Fiske, Cuddy, \& Glick, 2007).

Kepercayaan akan menciptakan dan mempertahankan hubungan pertukaran sosial yang pada akhirnya dapat menghasilkan berbagi pengetahuan yang berkualitas baik di antara karyawan.
Ketika ada kepercayaan ada di antara dua pihak, lebih bersedia untuk terlibat dalam interaksi berbagi pengetahuan(Nahapiet dan Ghoshal, 1998). Hasil penelitian McNeish dan Mann (2010) menjelaskan bahwa trustmerupakan antesenden dari berbagi pengetahuan Ketika trust di antara individu tinggi, maka kecenderungan individu untuk membagikan pengetahuan yang dimiliki kepada ornag lain juga akan meningkat (Liang, Liu, \& Wu, 2008; McNeish \& Mann, 2010). Karyawan yang memiliki pengetahuan mungkin tidak akan membagi pengetahuan yang dimiliki, kecuali jika mereka merasakan manfaat yang potensial. Sistem penghargaan (reward) yang bersifat monetary (keuangan) tidak cukup mendorong karyawan untuk menukarkan pengetahuan yang dimilikinya, karena penentu dalam hubungan pertukaran sosial adalah trust (Davenport \& Prusak, 1998; Wasko \& Faraj, 2005). Hal mendasar dari hubungan trustdan berbagi pengetahuanadalah adanya ikatan di antara karyawan yang dapat menjadi fasilitator berbagi pengetahuan. Institut IBM melakukan survei terhadap 138 karyawan dari perusahaan farmasi, bank, dan perusahaan minyak. Hasilnya adalah ditemukannya bahwa perilaku berbagi pengetahuanmembuat pekerjaan mereka menjadi lebih efektif dimana mereka percaya pada pengetahuan kompetensi rekan sekerjanya. Kepercayaan seorang individu dalam perilaku berbagi pengetahuandibangun melalui lingkungannya. DeLong (2004) mengatakan bahwa membangun kepercayaan untuk berbagi pengetahuan di antara karyawan memerlukan kemampuan pihak manajemen dalam pemahaman bahwa setiap pekerja memiliki pengetahuan yang perlu dibagi dan bagaimana cara terbaik untuk mendorong karyawan untuk berbagi pengetahuan yang mereka miliki. Jones dan George (1998) mengatakan 
bahwatrustsebagai konstruksi psikologi merupakan pengalaman hasil dari interaksi nilai, sikap, mood dan emosi. Ketika di dalam organisasi karyawan mulai dapat saling percaya satu sama lain, mereka menjadi lebih bersedia untuk membagikan sumber daya atau expertisenya tanpa khawatir akan diambil keuntungannya oleh pihak lain ( $\mathrm{Hsu}, \mathrm{Bi}$ Fen dkk, 2009). Nonaka (1994) menyatakan bahwa trustmerupakan hal yang penting dalam organisasi dan kelompok untuk meningkatkan atmosfer knowledge sharing (Hsu, Bi Fen dkk, 2009). Pendapat lain dikemukakan oleh Koskinen, dkk (2003) menyatakan bahwa trust memungkinkan adanya akses dan kesempatan berbagi pengetahuan dalam kelompok. Tiwana dan Bush (2005), Wang dan Yang (2008) menyatakan trustmempunyai pengaruh positif pada knowledge sharing dalam team yang nyata maupun virtual.

Dari hasil penelitian Holste dan Fields (2010) ditemukan bahwa trustmemiliki pengaruh yang sangat kuat terhadap perilaku individu dalam berbagi pengetahuantrustyang diukur untuk melihat hubungan kedua variabel adalahcognitive based trust, berarti instrumen trustdalam penelitian ini adalah ini kepercayaan berdasarkan bukti dan informasi kehandalan dan kompetensi rekan kerja dalam organisasi. Hal yang sama dikemukakan Forsythe (2006) bahwa trustmemiliki hubungan signifikan dengan knowledge sharing, penelitian dilakukan pada 140 mahasiswa yang juga merupakan pekerja. Trust yang digunakan pada penelitian ini juga difokuskan pada cognitive based trust. Dalam penelitian Qian dkk (2008) yang dilakukan pada karyawan perusahaan farmasi di amerika, ditemukan bahwa baik affect based trustdan cognitive based trustmemiliki pengaruh terhadap perilaku berbagi pengetahuan, dan dari hasil penelitian ditemukan bahwa cognitive based trustmemiliki pengaruh yang lebih kuat terhadap perilaku berbagi pengetahuan dibandingkan affect based trust.

Oleh karena itu, berdasarkan penjelasan diatas dapat dibangun hipotesis berikut :

$\mathrm{H} 1$ : Trustberhubungan positif dengan berbagi pengetahuan

Pada penelitian yang dilakukan oleh Kramer (1999) serta penelitian Levin dan Cross menyatakan bahwa kepercayaan yang muncul di lingkungan kerja memiliki pengaruh yang kuat terhadap beberapa fenomena organisasi seperti kepuasan kerja, stress, komitmen organisasi dan produktivitas.Morgan dan Hunt (1994) juga menyatakan bahwa trust merupakan salah satu faktor penentu dari komitmen. Berdasarkan penjelasan diatas maka diperlukan penelitian lanjutan untuk melihat korelasi antar kedua variabel. Berdasarkan penjelasan diatas, maka dibangun hipotesis berikut :

$\mathrm{H} 2$ : Trustberhubungan positif dengan komitmen organisasi

Komitmen organisasi merupakan sebuah konstruk yang unified (Hakim \& Viswevaran, 2005). Konstruk ini bisa dilihat dari sisi yang berbeda-beda. Perbedaan sisi pandang ini menyebabkan konstruk ini dikenal dengan berbagai macam isitilah yang berbeda-beda juga. Beberapa konstruk yang telah dipakai pada literatur-literatur penelitian terdahulu diantarnya adalah; organizational commitment (Wang \&Noe, 2010; Robins \& Judge, 2011; Schultz \& Schultz, 2010; McShane, 2010;) , affective commitment (Robbins \& Judge, 2011), employee commitment(Terry, 2002) serta work commitment (Hakim \& Viswesvaran, 2005; Carmeli and Freund, 2004). Sebagian besar literatur menggunakan konstruk 
komitmen organisasi (organizational commitment).

Komitmen organisasi telah didefinisikan dan dikonsepkan dengan berbagai macam cara beberapa dekade terakhir ini. Bahkan saat ini ada sejumlah variasi yang muncul yang berhubungan dengan bagaimana komitmen didefinisikan, dimensi konstruk, faktor yang mempengaruhi komitmen, dan dampak komitmen terhadap organisasi (Mayer, Becker, \& Vandenbergher, 2004). Pada umumnya sebagian besar studi mencirikan komitmen organisasi dalam konteks sebuah ikatan (bond atau attachment ) individu terhadap organisasi dan hal inilah yang bisa membedakan konstruk komitmen organisasi dengan konstruk kepuasan kerja.

Wang dan Noe (2010)

mendefinisikan komitmen organisasi sebagai derajat keterikatan seorang karyawan dengan organisasinya dan keinginan karyawan untuk mengerahkan segala usaha atas namaorganisasinya. Menurut Meyer, Allen, dan Smith (1993) komitmen organisasi merupakan kelekatan emosi, identifikasi, dan keterlibatan karyawan dalam perusahaan, serta keinginan untuk tetap menjadi anggota perusahaan.

Dari definisi-definisi yang dijelaskan diatas, peneliti menyimpulkan bahwa komitmen organisasi yang penulis maksudkan dalam penelitian ini adalah keterikatan seorang karyawan secara emosional terhadap pekerjaan dan organizasinya. Dengan adanya ikatan tersebut, karyawan mau dan berkeinginan untuk mengeluarkan segenap upaya untuk tetap bersama dengan organisasinya dalam mencapai tujuan. Oleh karena itu, seorang karyawan yang memiliki komitmen kerja yang tinggi akan sangat berpihak dengan pekerjaanya dan memiliki pengalaman perasaan positif dengan pekerjaanya dari pada karyawan yang memiliki komitmen rendah.
Karyawan dengan komitmen kerja yang tinggi tentunya akan memiliki keinginan untuk tetap bersama dengan pekerjaanya, senantiasa hadir bekerja dan mau mengeluarkan segenap usaha untuk melakukan pekerjaanya dengan sebaik mungkin.

Meyer, Allen, dan Smith (1993) membagi komitmen terhadap organisasi menjadi dalam tiga komponen yang berbeda yaitu komitmen sebagai kelekatan afeksi kepada organisasi, komitmen dipandang sebagai biaya yang timbul jika meninggalkan organisasi, dan komitmen sebagai kewajiban untuk tetap berada dalam organisasi, sehingga dapat dikatakan bahwa komitmen organisasi mengandung elemen keinginan, kebutuhan, dan kewajiban.

Berdasarkan tiga komponen tersebut, Meyer Allen, dan Smith (1993) mengajukan konsep tiga komponen komitmen organisasi, yaitu komitmen afektif, komitmen kontinuitas, dan komitmen normatif. Komitmen afektif yang berkaitan dengan aspek emosional, identifikasi, dan keterlibatan karyawan dalam organisasi. Komitmen afektif merupakan proses sikap dimana seseorang berpikir tentang hubungannya dengan organisasi dengan mempertimbangkan kesesuaian antara nilai dan tujuannya dengan nilai dan tujuan organisasi. Komitmen kontinuitas yaitu persepsi karyawan tentang kerugian yang akan dihadapinya jika ia meninggalkan perusahaan. Komitmen normatif yang merupakan perasaanperasaan seperti tanggungjawab, loyalitas, atau kewajiban moral terhadap organisasi. Pada akhirnya, komponen normatif mengacu kepada keterlibatan individu berdasarkan pada perolehan terhadap rewards extrinsic tertentu. komitmen organisasi telah ditemukan terkait dengan organizational variables, seperti turnover, kepuasan kerja, sense of 
obligation, dan membantu orang lain (Meyer, Allen, \& Smith 1993).

Storey and Quintas (2001) menyarankan pengembangan trust, motivation, dan komitmen karyawan mewakili isu utama dalam hubungan terhadap knowledge management pekerja. Hal ini penting karena karyawan dengan komitmen organisasi yang tinggi cenderung rendah untuk meninggalkan perusahaan, dan mereka cenderung memiliki motivasi yang tinggi, dan lebih mungkin untuk melakukan pekerjaan ekstra dan secara umum lebih ingin untuk melakukan berbagi pengetahuan didalam organisasi. Bagaimanapun, apakah level komitmen mempengaruhi sikap atau partisipasi di dalam inisiasinya melakukan berbagi pengetahuan menjadi pertanyaan yang perlu dijawab dan belum ada penelitian yang telah dilakukan untuk hal ini (Hislop, 2003).

Dari penjelasan konsep komitmen organisasi serta beberapa penelitian terdahulu yang memerlihatkan hubungan antara komitmen organisasi dan berbagi pengetahuan, maka pada penelitian ini terbangun suatu hipotesis berikut :

H3: Komitmen organisasi berhubungan positif dengan berbagi pengetahuan.

\section{Model Penelitian}

Dari beberapa hipotesis yang diajukan dalam penelitian ini, maka terbentuk suatu model penelitian yang digambarkan dalam bagan berikut:

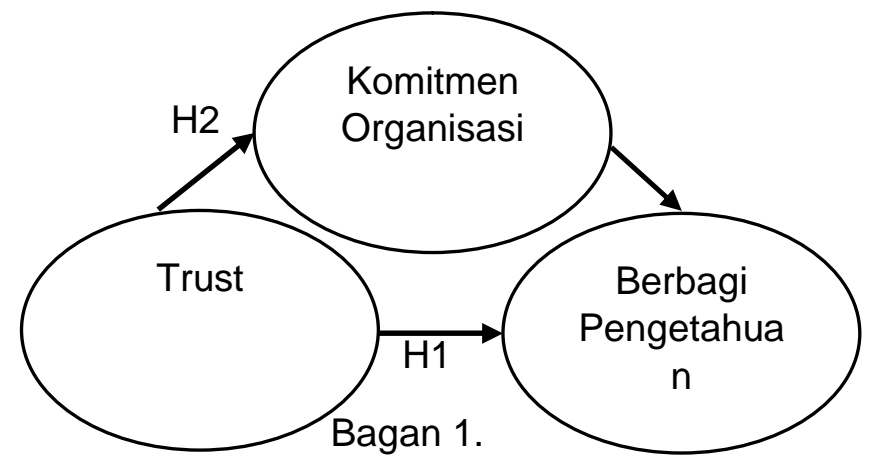

$\mathrm{H} 1$ :Trust berhubungan positif dengan berbagi pengetahuan

H2: Trust berhubungan positif dengan komitmen organisasi

H3: Komitmen organisasi berhubungan positif dengan berbagi pengetahuan

\section{METODE PENELITIAN}

Penelitian ini merupakan penelitian kuantitatif dengan menggunakan kuesioner sebagai bentuk pengumpulan data. Kuesioner yang diberikan baik dalam bentuk online yang disebarkan melalui jejaring sosial dan aplikasi seperti Line, Whatsapp, email, BBM, dan lainnya serta dalam bentuk kuesioner kertas yang disebarkan langsung ke universitasuniversitas negeri maupun swasta. Total responden yang telah mengisi berjumlah 150 responden yang berasal dari beberapa daerah dan Universitas di Indonesia.

Dari data yang peneliti terima jumlah responden laki-laki sebanyak 39\% dan $61 \%$ berjenis kelamin perempuan. Selanjutnya untuk tingkat pendidikan terakhir $10 \%$ responden memiliki jenjang pendidikan strata satu, 71 persen responden memiliki jenjang pendidikan terakhir strata dua, dan $19 \%$ responden memiliki jenjang pendidikan terakhir strata tiga. Untuk penggolongan usia responden, $61 \%$ responden berada di rentang usia 25-35 tahun, 31\% responden berada di rentang usia 35 - 55 tahun, dan 8\% responden berada di rentang usia 55 tahun ke atas.

Penelitian ini menggunakan alat ukur dari McAllister (1995) untuk mengukur Trust (Kepercayaan) dengan reliabilitas sebesar 0,73 dengan contoh item "Saya akan membagi ide besar dan harapan saya dengan rekan dosen tertentu". Komitmen Organisasi menggunakan alat ukur dari Allen dan Meyer (1990) dengan contoh 
item "Saya merasa berkembang bersama dengan perkembangan Perguruan Tinggi ini" dengan besaran realibilitasnya 0,88. Sedangkan untuk Berbagi Pengetahuan menggunakan alat ukur yang dikembangkan oleh Hoff dan deRidder (2004) dengan angka reliabilitas sebesar 0,88 dengan contoh item "Saya akan membagi informasi dan pengetahuan yang saya miliki kepada dosen lainnya".

Tabel 1

\begin{tabular}{|c|c|c|c|}
\hline Variabel & $\begin{array}{l}\text { Alat } \\
\text { ukur }\end{array}$ & Reliabilitas & Contoh item \\
\hline $\begin{array}{l}\text { Berbagi } \\
\text { Pengetahuan }\end{array}$ & $\begin{array}{l}\text { Hoff \& } \\
\text { Ridder } \\
(2004)\end{array}$ & .88 & $\begin{array}{l}\text { Saya akan } \\
\text { membagi } \\
\text { informasi dan } \\
\text { pengetahuan } \\
\text { yang saya } \\
\text { miliki kepada } \\
\text { dosen lainnya }\end{array}$ \\
\hline Trust & $\begin{array}{l}\text { McAllister } \\
(1995)\end{array}$ & .73 & $\begin{array}{l}\text { Saya akan } \\
\text { membagi ide } \\
\text { besar dan } \\
\text { harapan saya } \\
\text { dengan rekan } \\
\text { dosen tertentu } \\
\text { ditargetkan }\end{array}$ \\
\hline $\begin{array}{l}\text { Komitmen } \\
\text { Organisasi }\end{array}$ & $\begin{array}{l}\text { Meyer \& } \\
\text { Allen } \\
(1990)\end{array}$ & .88 & $\begin{array}{l}\text { Saya merasa } \\
\text { berkembang } \\
\text { bersama } \\
\text { dengan } \\
\text { perkembangan } \\
\text { Perguruan } \\
\text { Tinggi ini }\end{array}$ \\
\hline
\end{tabular}

Aitem dalam ketiga kuesioner berikut masih menggunakan Bahasa Inggris sehingga proses back-tobacktranslation digunakan untuk menerjemahkan Bahasa Inggris menjadi Bahasa Indonesia dan kembali ke Bahasa Inggris lagi untuk menjamin hasil terjemahan yang baik. Setelah itu peneliti akan menggunakannya untuk mengumpulkan data. Pilihan jawaban untuk item-item diatas terdiri dari 4 pilihan yaitu $1=$ sangat tidak setuju, $2=$ tidak setuju, 3 = setuju, $4=$ sangat setuju.

\section{HASIL dan PEMBAHASAN}

Berdasarkan uji validitas ditemukan bahwa semua alat ukur yang digunakan dinyatakan valid karena memiliki $p<.05$ dan $r$ tabel yang lebih kecil dari $r$ hitung dengan $d f=148$. Untuk hipotesis pertama $\mathrm{p}$ value. Untuk hipotesis $\mathrm{H} 1, p$-value sebesar 0,000 dimana membuktikan bahwa terdapat trust pada dosen mempengaruhi berbagi pengetahuannya. Untuk hipotesis $\mathrm{H} 2$ juga terbukti berpengaruh dimana besaran $p$-value adalah 0,0028. Hal ini membuktikan bahwa trust pada dosen berpengaruh terhadap komitmen dosen. Sedangkan untuk hipotesis $\mathrm{H} 3$ juga terbukti memiliki pengaruh antara komitmen organisasi dosen terhadap berbagi pengetahuan dosen dengan nilai $p$-value 0,0048 .

\section{SIMPULAN}

Hasil penelitian ini menunjukkan bahwa terhadap hubungan yang positif antara Trust terhadap Berbagi Pengetahuan. Hal ini sesuai dengan beberapa penelitian sebelumnya yang menunjukkan bahwa Trust memiliki pengaruh yang positif terhadap Berbagi pengetahuan (Nahapiet dan Ghoshal, 1998; McNeish \& Mann, 2010; Liang, Liu, \& Wu, 2008; Hsu, Bi Fen dkk, 2009; Wang \& Yang, 2008). Dengan adanya trust pada dosen, maka atmosfir berbagi pengetahuan lebih mudah tercipta sehingga memungkinkan dosen untuk berbagi pengetahuan. Penelitian Holste dan Fields (2010) juga mengemukakan bahwa trust memiliki pengaruh yang sangat kuat terhadap perilaku individu dalam berbagi pengetahuan. 
Trust (kepercayaan) yang muncul di lingkungan kerja memiliki pengaruh yang kuat terhadap beberapa fenomena organisasi seperti kepuasan kerja, stress, komitmen organisasi dan produktivitas. Hal ini sejalan dengan hasil dari penelitian ini dimana Trust memiliki efek yang positif terhadap komitmen dosen terhadap perguruan tinggi dimana dosen tersebut bekerja.

Dalam studi ini ditemukan bahwa terdapat hubungan yang positif antara Komitmen Organisasi dosen terhadap Berbagi Pengetahuan. Dosen yang memiliki komitmen tinggi cenderung untuk berada dalam institusi yang sama dan mereka cenderung memiliki motivasi yang tinggi sehingga memungkinkan mereka untuk melakukan pekerjaan yang ekstra serta lebih ingin berbagi pengetahuan mereka baik kepada mahasiswa maupaun rekan-rekan mereka.

Penelitian tentang Berbagi Pengetahuan masih sangat terbatas di Indonesia sehingga topik ini masih sangat luas untuk diteliti terutama pada dosendosen. Penelitian lanjutan bisa dilakukan dengan menambahkan variabel-variabel yang terkait dengan berbagi pengetahuan maupun menambahkan variabel-variabel yang belum terjawab pada penelitian ini.

Terdapat beberapa keterbatasan dalam penelitian ini dimana masih sedikitnya jumlah partisipan penelitian. Jumlah partisipan yang lebih besar bisa memberikan keragaman data yang lebih besar.

\section{DAFTAR PUSTAKA}

Alavi, M., Kayworth, T., Leidner, D., (2006). An empirical examination of the influence of organizational culture on knowledge management practices, 22 (3), 191-224.

Arthur, J. B., \& Huntley, C. L. (2005). Ramping up the organizational culture curve : Assesing the impact of deliberate learning on organizational performance under gainsharing. Academy of Management Jounral, 48(6), 1159-1170.

Bateman, T.S. \& Organ, D.W. 1983. Job Satisfaction and The Good Soldier: The Relationship Between Affect and Employee "citizenship". Academy Of Management Journal, 26 (587-595)

Becerra-Fernandez, I., Gonzalez, A. \& Sabherwal, R. (2004). Knowledge management: challenges, solutions, and technologies. New Jersey : Pearson/Prentice Hall.

Bock, G., Lee, J., Zmud, R., \& Kim, Y. (2005). Behavioral intention formation in knowledge sharing: Examining the roles of extrinsic motivators, social-psychological forces, and organizational climate. MIS Quarterly, 29, 87-111.

Bolino, M.C., Turnley, W.H. and Bloodgood, J.M. (2002), "Citizenship behaviour and the creationof social capital in organizations", Academy of Management Journal, 27 (4) 505-22.

Bollinger, A.S., \& Smith, R.D. (2001). Managing organizational knowledge as a strategic asset. Journal of Knowledge Management, 5 (1), 8-18.

Boyd, J., Ragsdell, G. \& Oppenheim, C. (2007). Knowledge transfer mechanisms: a case study from manufacturing, in Martins, B. and Remenyi, D. (Eds), Proceedings of the 8th European Conference on Knowledge Management, Academic Conference Reading, pp. 139-146. 
Burud, S., \& Tumolo, M. (2004). Leveraging the new human capital. Mountain View, CA: Davies-Black.

Cabrera, A., \& Cabrera, E. F. (2002). Knowledge-sharing dillemas. Organization Studies, 23, 687-710.

Carmeli, A., \& Freund, A. (2004). Work commitment, job satisfaction, and job performance: an empirical investigation. International Journal of Organization Theory and Behavior, 7 (3),

Carter, C., \& Scarbrough, H. (2001). Towards a second generation of KM? The people management challenge. Education \& Training, 43(4), 215-224.

Casimir, G., Lee, K., \& Loon, M. (2012). Knowledge sharing: influences of trust, commitment and cost. Journal of Knowledge Management, 16.(740 - 753)

Cavaliere, V,.\& Lombardi, S,. (2015). Exploring different cultural configurations : How do they affect subsidiaries' knowledge sharing behaviors?". Journal of Knowledge Management, 2, 141-163.

Cheng \& $\mathrm{Li}, 2006$. The relationships of organization justice, trust and knowledge sharing behaviors. Journal of Human Resource Management, 1, 69-93.

Chowdhury, Sanjib. (2005). The Role of Affect- and Cognition-based Trust in Complex Knowledge Sharing.Journal of Managerial Issue. 17 (3)

Collins, C. J., \& Smith, K. G. (2006). Knowledge exchange and combination : The role of human resource practices in the performance of high-technology firms. Academic of Management Journal, 49(3), 544-560.

Cummings, J. N. (2004). Work groups, structural diversity, and knowledge sharing in a global organization. Management Science, 50(3), 352-364.

Cheng M. Y., Ho J. S. Y., \& Lau, P. M. (2009). KS in Academic Institutions: a Study of Multimedia University Malaysia. Electronic Journal of KM. Vol 7 (3), 313-324

Chiang, H. H., Han, T. S., Chuang, J. S. (2011). The relationship between high-commitment HRM and knowledge-sharing behavior and its mediators. International Journal of Manpower.Vol. 32 No. 5/6, 2011 pp. 604-622. DOI 10.1108/01437721111158224.

Chiu, C. M., Hsu, M. H., \& Wang, E. (2006). Understanding knowledge sharing in virtual communities: An integration of social capital and social cognitive theories. Decision Support Systems, Vol. 42, No. 3, 1872-1888.

Chua, Roy Y.J., P. Ingram., \& M. Morris. (2008). From the Head and the Heart: Locating Cognition- and Affect-based Trust in Managers' Professional Networks. Academy of Management Journal, Vol. 51, No. 3, 436-452.

Damodaran, L., \& Olphert, W. (2000). Barriers and facilitators to the use of knowledge management systems. Behaviour \& Information Technology, 19(6), 405-413.

Davenport, T. H., \& Prusak, L. (1998). Working knowledge : How Organizations manage what they know. Boston, Ma: Harvard Business School Press.

De Vries, R. E., van den Hoof, B., \& de Ridder, J. A. (2002). Expalining knowledge sharing : The Role of team communication styles, job satisfaction, and performance beliefs. Communication Research, 33(2), 115-135. 
Fang, Y. H., Chiu, C. M. (2009). In justice we trust: Exploring knowledge-sharing continuance intentions in virtual communities of practice. Computers in Human Behavior. Vol 26 (2010) 235-246.

Fiske, S. T., Cuddy, A. J. C., \& Glick, P. (2007). Universal dimensions of social cognition: Warmth, then competence. Trends in Cognitive Science, 11, 77-83.

Forsythe, S., Liu, C., Shannon, D., and Gardner, L.C. "Development of a scale to measure the perceived benefits and risks of online shopping," Journal of Interactive Marketing (2:2) 2006, pp. 55-75.

Flynn, F.J. (2005), "Identity organizations and forms of social exchange in organization", Academy of Management Review, Vol. 30 No. 4, pp. 737-50.

Fullwood, R., Rowley, J., Delbdride, R. (2012). Knowledge sharing amongst academics in UK universities. Journal of Knowledge Management. Vol. 17 No. 1 2013, pp. 123-136. DOI 10.1108/13673271311300831.

Gagne, M. (2009). A model of knowledge-sharing motivations. Human Resource Management, Vol. 48, No. 4, 571-589.

Grant, R.M. (1996), "Toward a knowledge-based theory of the frm", Strategic Management Journal, Vol. 17 No. 2, pp. 109-122.

Gray, J. H., Densten, I. L., 2005. Towards an integrative model of organizational culture and knowledge management. International Journal of Organisational Behaviour, Vol. 9 (2), 594-603.

Gupta, A. K., \& Govindarajan, V. (2000). Knowledge management's social dimensions: Lessons from Nucor Steel. Sloan Management Review, 42(1), 71-80.

Gyamfi, F,. Boenteng, H,.\& Dzandu, D, M,. (2016). Knowledge Sharing among Teacher; The role of big five personality traits. Journal of Knowledge Management, 46, 64-86.

Hakim, A.C., \& Viswesvaran, C. (2005). The construct of work commitment: testing an integrative ramework. Psychological Bulletin . The American Psychological Association, Vol. 131, No. 2, 241-259

Hislop, D. (2003). Linking human resource management and knowledge management via commitment : a review and research agenda. Employee Relations. Vol. 25, pp 182202.

Holste, J. S., \& Fields, Dail. (2010). Trust and Tacit Knowledge Sharing and Use. Journal of Knowledge Management, Vol.14, No.1, 128-140.

Hooff, B.v.d. \& Weenen, F.d.L. (2004). Commited to share : commitment and CMC use as antecendents of knowledge sharing. Knowledge and Process Management. Vol. 11, pp. 13-24.

Hsu, Bi Fen., Wu, Wei L., \& Yeh, Song Ryh (2009). Interpersonal Trust and Knowledge Sharing: Moderating Effects Of Individual Altruism And a Social Interaction Environment. Social Behaviour and Personality. Vol 37, No. 1.

Hsu, C.L. and Lin, J.C.C. (2008). Acceptance of blog usage: the roles of technology acceptance,social influence and knowledge sharing motivation. Information \& Management, Vol. 45,pp. 65-74. 
lyer, G., Ravindran, S. (2013). Organizational Commitment, Knowledge Management Initiative Importance and Success Likelihood as Antecedents of Knowledge Sharing Intention: An Exploratory Study. Proceedings of the Nineteenth Americas Conference on Information Systems, Chicago, Illinois, August 15-17, 2013.

Jo, J. S. \& Joo, B. K. (2011). Knowledge sharing: the influences of learning organization culture, organizational commitment, and organizational citizenship behaviors. Journal of Leadership \& Organizational Studies, 18(3) 353-364.

Johannessen, J. A., Olaisen, J., Olsen, B. (2001). Mismanagement of tacit knowledge: the importance of tacit knowledge, the danger of information technology, and what to do about it. Journal International Journal of Information Management: The Journal for Information Professionals. Volume 21 Issue 1, February, 2001 Pages 3-20.

Kankanhalli, A., Tan, B. C. Y., \& Wei, K. K. (2005). Contributing knowledge to electronic knowledge repositories :An empirical investigation. MIS Quarterly, 29(1), 113-143.

Kim, S., and Ju, B. (2008). An analysis of faculty perceptions: Attitudes toward knowledge sharing and collaboration in an academic institution. Library \& Information Science Research 30(4): 282-290

Kim, S., \& Lee, H. (2006). The impact of organizational context and information technology on employee knowledge-sharing capabilities. Public Administration Review, 66(3), 370-385.

Kogut, Bruce, and Udo Zander. (1996). What firms do? Co-ordination, identity and learning. Organizational Science 7(5): 502-510.

Kramer, R. M. (1999) 'Trust and Distrust: Emerging Questions, Enduring Questions',Annual Review of Psychology 50: 569-98.

Levin, D. Z. and Cross, R. (2004) 'The Strength of Weak Ties You Can Trust: The Mediating Role of Trust in Effective Knowledge Transfer', Management Science 50(11): 147790.

Liang, T. P., Liu, C. C, \& Wu, C. H. (2008). Can social exchange theory explain individual knowledge-sharing behavior? A meta-analysis", In: ICIS 2008.

Liew, A. (2007). Understanding data, information, knowledge and their inter-relationship. Journal of Knowledge Management Practice, Vol.8, No.2.

Lin. (2007). Effects of extrinsic and intrinsic motivation on employee knowledge sharing intentions. Journal of Information Science, Vol 33, 135-149.

Mayer, J. P., Becker, E. T., \& Vandenbergher, C. (2004). Employee commitment and motivation: a conceptual analysis and integrative model. Journal of Applied Psychology. Vol. 89, No. 6.00 DOI: 10.1037/0021-9010.89.6.991

McAllister, D. J. (1995). Affect- and cognition-based trust as foundations for interpersonal cooperation in organizations. Academy of Management Journal, 38(1), 24-59.

McEvily, B., V. Perrone., \& A. Zaheer. (2003). Trust as an organizing principle. Organization Science, Vol. 14, 91-103.

McNeish, J., \& Mann, I. J. S. (2010). Knowledge sharing and trust in organizations. The IUP Journal of Knowledge Management, 8(1\&2), 18-38. 
Mesmer-Magnus, J. R., \& DeChurch, L. A. (2009). Information sharing and team performance : A meta-analysis. Journal of Applied Psychology, 94, 535-546.

Meyer, J. P. \& Allen, N. J. (1997). Commitment in the Workpalce : Theory, Research and Application. Sage, Thousand Oaks, California.

Meyer, J. P., Allen, N. J., \& Smith, C. A. (1993). Commitment to organizational and occupations: Extension and test of a three component conceptualization. Journal of Applied Psychology, 78 (4), 538- 551.

Mooradian, T., Renzl, B., \& Matzler, K. (2006). Who trusts? Personality, trust and knowledge sharing. Management Learning, 37(4), 523-540.

Morgan, R.M. and S.D. Hunt. "The Commitment-Trust Theory of Relationship Marketing," Journal of Marketing, (58), July 1994, pp. 20-38.

Nonaka, I. \& Takeuchi, H. (1995). The Knowledge-creating Company. How Japanese Companies Create the Dynamics of Innovation. Oxford University Press, Oxford.

Nonaka, I., Toyama, R. and Nagata, A. (2000), "A firm as a knowledge-creating entity: a new perspective on the theory of the frm", Industrial and Corporate Change, Vol. 9 No. 1, pp. 1-20.

O'Reilly, C. \& Chatman, J. (1986). Organizational commitment and psychological attachment: the effects of compliance, identification and internalization on prosocial behavior, Journal of Applied Psychology, 71: 492-9.

Organ, D.W. (1988). Organization Citizenship Behavior: The good soldier syndrome. Lexington, MA: Lexington Books.

Podsakoff, P. M., MacKenzie, S. B., Moorman, R. H., \& Fetter, R. (1990). Tranformational leader behaviors and their effect on followers trust in leader, satisfaction, and OCB. Leadership Quarterly, 1, 107-142.

Podsakoff, P.M., MacKenzie, S.B., Paine, J.B. and Bachrach, D.G. (2000). "Organizationalcitizenship behaviors: a critical review of the theoretical and empirical literature andsuggestions for future research", Journal of Management, Vol. 26 No. 3, pp. 513-63.

Prahalad, C. K, and Hamel, G. (1990). The core competition of the corporation. Harvard Business Review 68(3): 79-91.

Ramachandran, S.D., Chong, S.C. and Ismail, H. (2009). "The practice of KM processes: a comparative study of public and private higher education institutions in Malaysia". VINE:The Journal of Information and Knowledge Management Systems, Vol. 39 No. 3, pp. 203-222, doi: 10.1108/03055720911003978.

Ridzuan, Abang Ahmad, Kian Sam Hong, and Mohd Asri Adanan. 2008. Knowledge managementpractices in higher learning institutions in Sarawak. Asian Journal of University Education 4(1):69-89.

Riege, A. (2005). Three-dozen knowledge-sharing barriers managers must consider. Journal of Knowledge Management, 9(3), 18-35.

Robins, S. P., \& Judge, T. A. (2011). Organizational behavior fourteenth edition. New Jersey: Pearson Education, Inc. 
Robertson, M., \& Hammersley, G. (2000). Knowledge management practices within a knowledge-intensive firm: The significance of the people management dimension. Journal of European Industrial Training, 24, 241-253.

Sandhu, M. S., Jain, K. K., \& Ahmad, I. U. K. B. (2011). Knowledge sharing among public sector employees: evidence from Malaysia. International Journal of Public Sector Management, 24(3), 206-226.

Schultz, D., \& Schultz, S.E. (2010). Psychology and Work Today tenth edition. New Jersey: Pearson Education, Inc.

Szulanski, G., Cappetta, R., \& Jensen, R. J. (2004). When and how trustworthiness matters: Knowledge transfer and the moderating effect of causal ambiguity. Organization Science, 15, 600-613.

Terry, B. (2002). Improve employee commitment. Industrial Management, Jul/Aug 2002; 44, 4.

Tiwana, A. \& Bush, A. A. (2005). Continuance in Expertise-Sharing Networks: A Social Perspective. leee Transactions on Engineering Management, vol. 52, no. 1, february 2005.

Tsai, W. (2002). "Social structure of "coopetition" within a multiunit organization : coordination, competition, and intraorganizational knowledge sharing". Organizational Science, Vol 13 No 2, pp 179-190.

Tsoukas, H. and Vladimirou, E. (2001), "What is organizational knowledge?", Journal of Management Studies, Vol. 38 No. 7, pp. 973-993.

Tuomi, I. (1999). Data Is More Than Knowledge: Implications of the Reversed Knowledge Hierarchy for Knowledge Management and Organizational Memory. Journal of Management Information Systems, Vol. 16, No. 3.

Tyler, T.R. (2003). Trust within organization. Personal Review,32(5), 556-568.

Voelpel, S. C., Dous, M., \& Davenport, T. H. (2005). Five steps to creating globa knowledgesharing systems : Siemens ShareNet. Academy of Management Executive, 19(2), 923.

Wang, C. C., \& C. Y. Lai, (2006). Knowledge contribution in the online virtual community: Capability and motivation. Knowledge Science Management, : 442-453.

Wang, S. \& Noe, R. A. (2010). Knowledge sharing: a review and directions for future research. Human Resource Management Review, 20 (2010) 115-131.

Wasko, M. M., \& Faraj, S. (2000). "It is what one does" : Why people participate and help others in electronic communities of practice. The Journal of Strategic Information Systems, 9(2-3), 155-173.

Wickramasinghe, V., \& Widyaratne, R. (2012). Effects of interpersonal trust, team leader support, rewards, and knowledge sharing mechanisms on knowledge sharing in project teams. Vine, 42(2), 214-236. 
Yao, L. J., Kam, T. H. Y., \& Chan, S. H. (2007). Knowledge sharing in Asian public administration sector: The case of Hong Kong. Journal of Enterprise Information Management, 20(1), 51-69.

Yu, C., \& Chu, T. (2007). Exploring knowledge contribution from an OCB perspective. Information \& Management, 44, 321-331 